\title{
—座談會記 錄—
}

\section{平和產業に對する材料}

\section{機械材料部門委員會)}

\section{出席者}

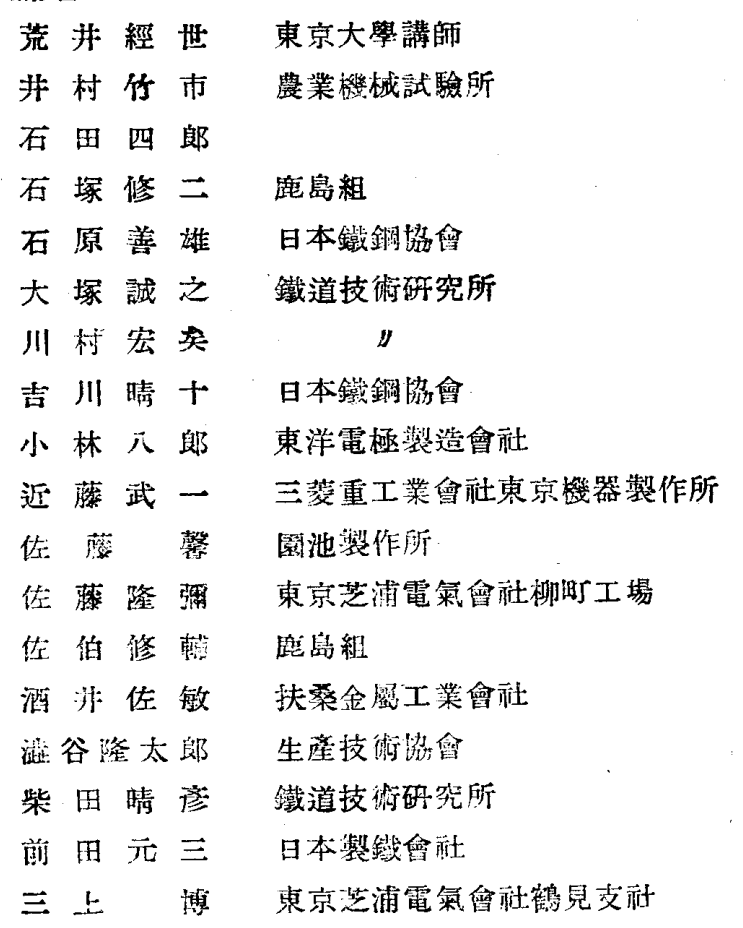

宫崎 好文化學機械學會

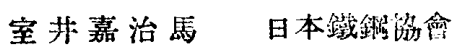

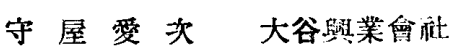

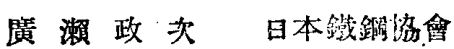

湯川正夫日本貿鐵會祉

野口何一日本機㖪學會々長

\section{機栈材料部門委員會}

委員長山网弘早稻时大學

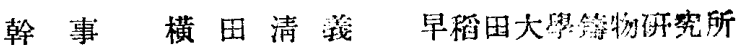

委員石田求野村㢣錩會泣:

内田侄一東京亡業大學

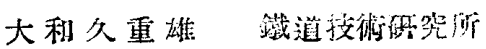

岡本正三束京工業大學

加山延太郎早稳田大學镜物研究所

河田利美䜌工省端械試驗所

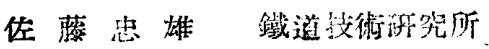

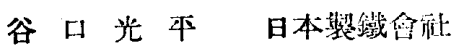

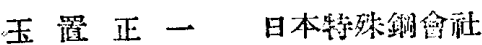

山內委員長 御怒內のごとく今般本會機杫㭁料部 胜委䝿會にて「本和斑業に對す万材料の座談會を計 冀致して開催しましたこころ，御多し中のところをお゙

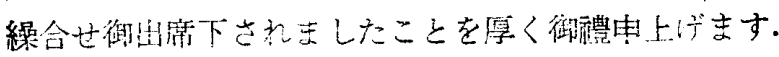

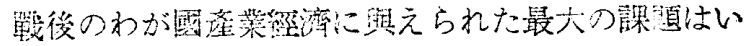

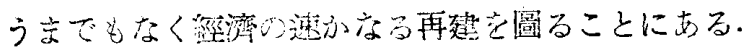

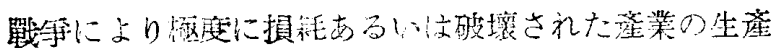

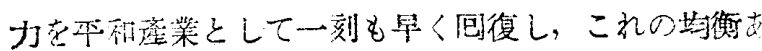

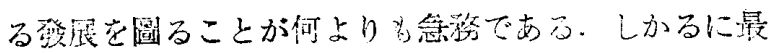

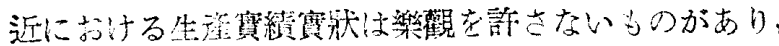

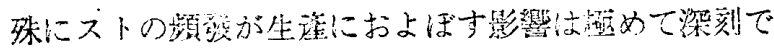

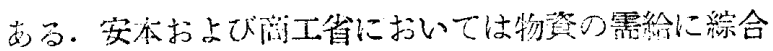

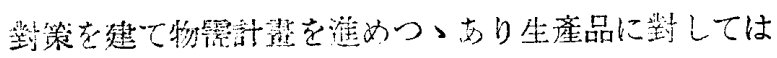

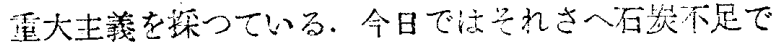

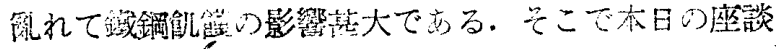

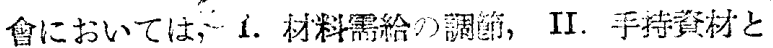

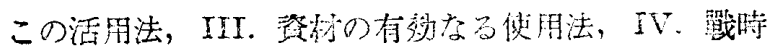

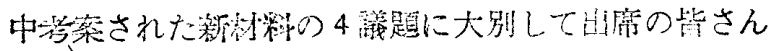
のお話しを承わり，お互に協力して生座の范機の打開

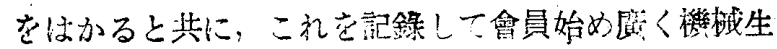

產の方のの參洘にも供したいと思います。何分間題は

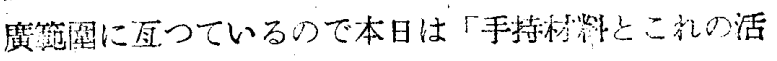
用注:に重㘶をおくことに㳊したく存じます。

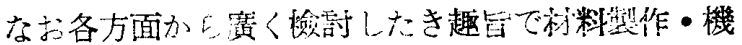

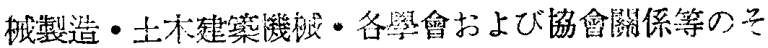

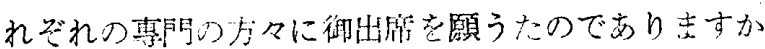

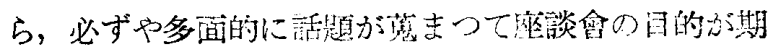

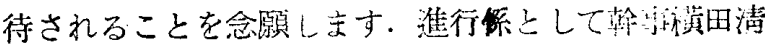

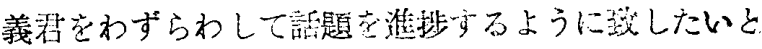
思います。

で注これより座談鼠にはいることに斑しますが，始

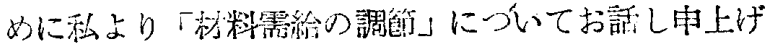
ます。

いまさらいうまでもなく現在の因本は一床立ちの國

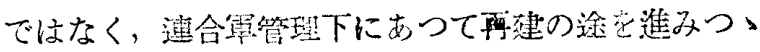

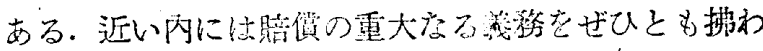
ねばならない，忠蕒にこれを能行するためにさらにま

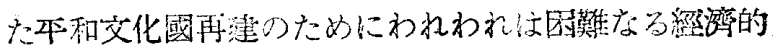

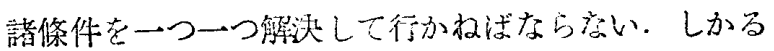
に最近の生產の賽狀は樂觀を哔さ放ものがあり，終戰 


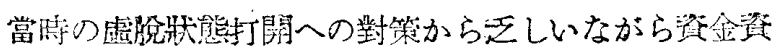

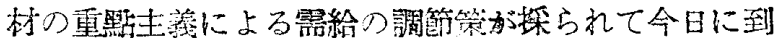

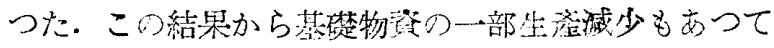

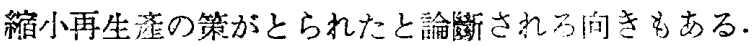

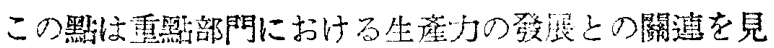
極めた上でないと論斷忟困難りようではあるが，首相 その他の人々か議會において，在庯生產資材の枯渴は いまや念激に近ずき，わが國基整物签の供給は重大な

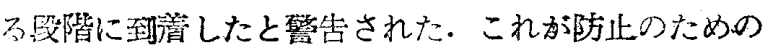

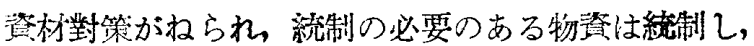
また國家管理も行われようとしており，縮小再生產を

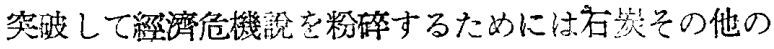

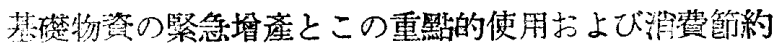

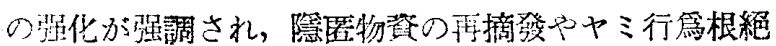
に對する國巨運動の展開も企圆されている。

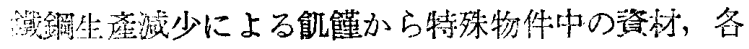

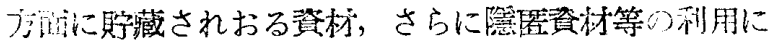
ついて注限度があり，すでにストックの缺乏立生產に とつて致命的なものであるのであらゆるエ夫と努力が

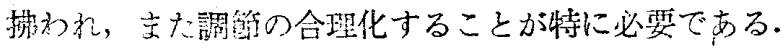

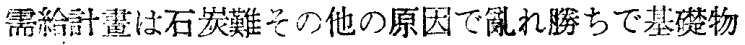
登り生產さえも振わない現狀であるから，機柩生產部

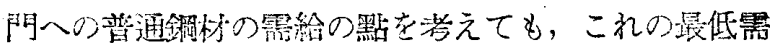

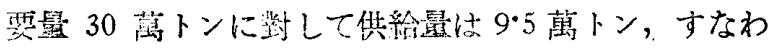
ち約 32\%の供給に㣂ぎいことが報ぜられている。 生崖力の發展を渴る本來の监格としては機戍部間換言

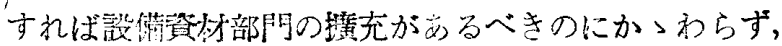

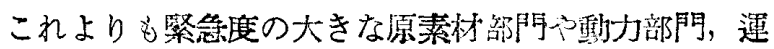

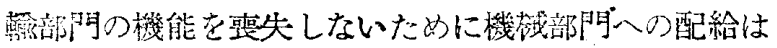
最当後趣しとされているという誠に篣給の逼迫した狀 沉にあること亦䠛明されている。

すでに述べたように，政戰國としての瞕償は浧合軍 に對する義務である。同時に賠償に件なう國內經濟へ の影響をできるだけ除去するように努力することはわ

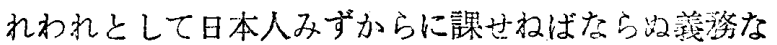
のであ万と思う。われわれとして國家の政治的紋定に。 坫力すべきものは，もちろん進んで一致略力すると共

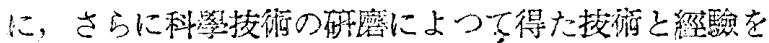

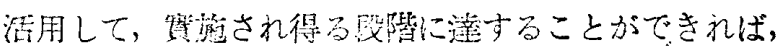

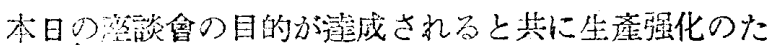
めに少なから好筫衙となることを信じ，各位の㙏藏な

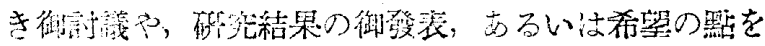
卧げられることを念愿し，また期待申すところであり ます。

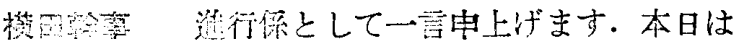

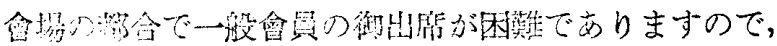

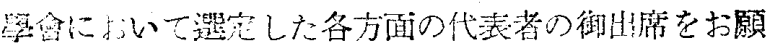

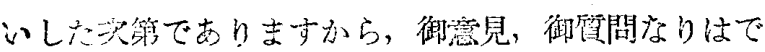

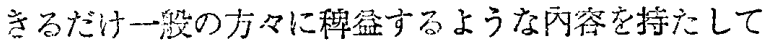

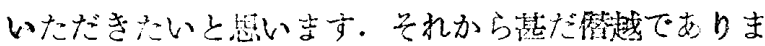

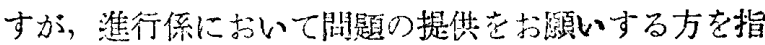
名させていただきます。

それで恃座談に對する一般的な御意胃を啮谷さんに 伺います。

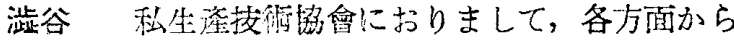

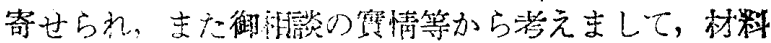

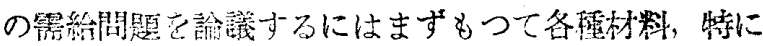

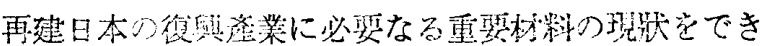

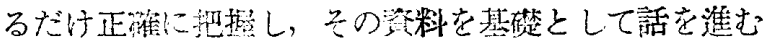
べきであると舁います。すなわち第 1 に各種材料の保

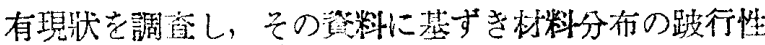
を修正し得る如き彼此呺通の案を樹て，あるい位停消

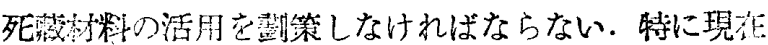

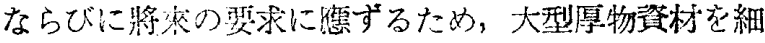
物灅物に再加工するような筫行案はぜひとも必要であ る。第2 には各種北料の生產現狀を調查し，それによ

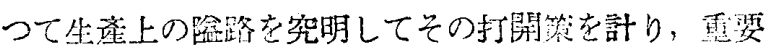

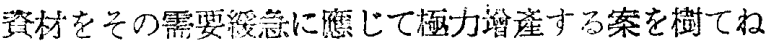

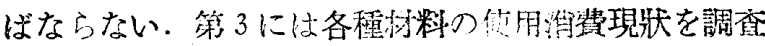
して，不急作業に使用される材料就これを䇣等作策に

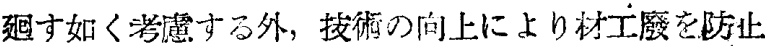

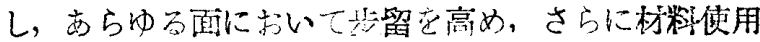

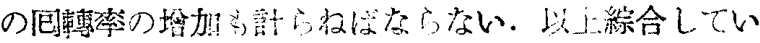

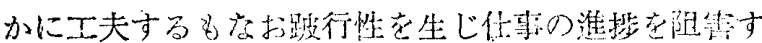

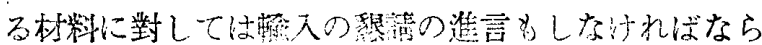

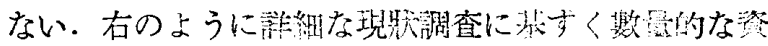

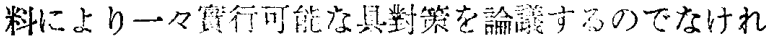

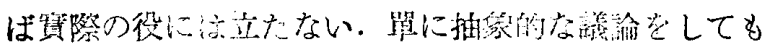
空諭に終ろのみである。とこうがわが圈には以上り上 うな再要な事項でも正確な記鉒や統計柱とれておらな

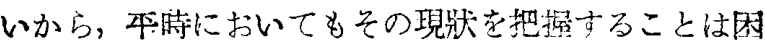

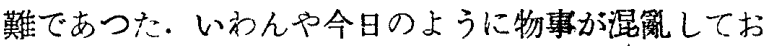
る爿起で汇，何にもか子解らないのが當然であるが， これをこのまつにして掞げてしまへば，知らぬ間に取 り退しのつか女事態に追い込まれることになろう。し たがつてもしできることならば，現湯睍物と物の動き を熟知する公平な人々ができるだけの资料を持ち簿り 材料つ現狀をまとめられることが望ましい．特に目下 行われている材料割當配給の方法等において改善を必 姴と認むるもの结，遠愿することなく改正方を提案す べきである。ところが從來の經羷によりますと，汪ん とうに材料の所在京知つているものは，なかなか告白”

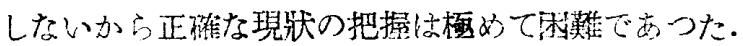

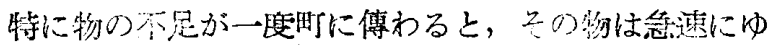
くえをくらまして不足の定を樑刻化し，ますます琴贆 を不明にするのが一般の傾向である。結征个日の如く 何にもかも不足ということにな礼ばずでてのもが

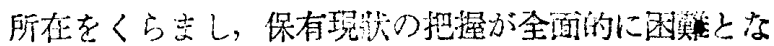




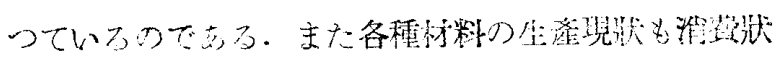

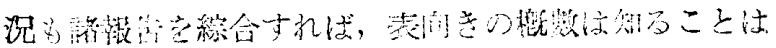

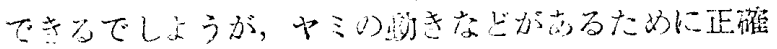

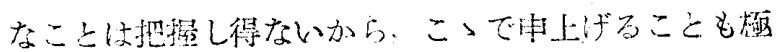

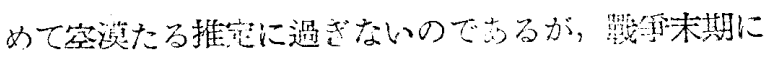

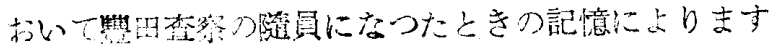

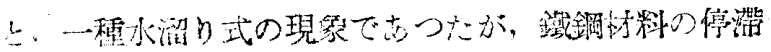

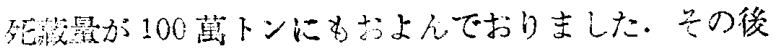

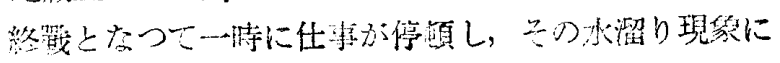

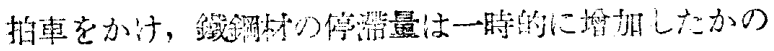

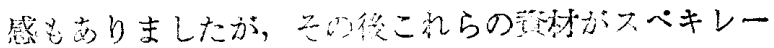

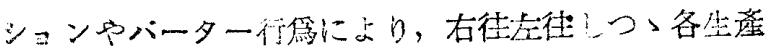

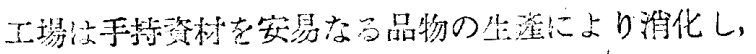

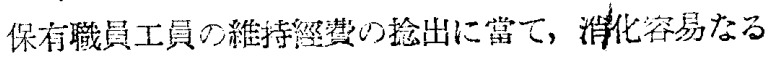

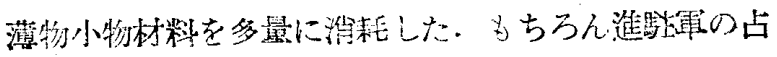

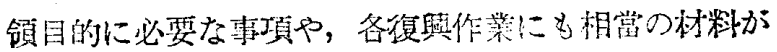
使用されたがここの間ほとんと新しい生產の見るべき ものがなかつたため，今日において郎時使用矿能な 手頃の重要資材はいずれも底をつかんとしているので 㳉ないかと感ぜられます。この重裂检材の㭕澏により，

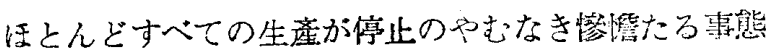
に陷るべきことが蹊感されますのた，一日も活机に れらの筫情を㒛查確認し，いつわらない現思を國民の

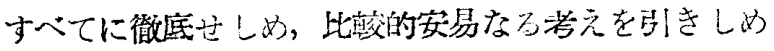

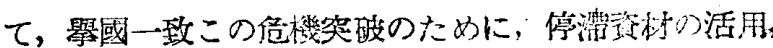

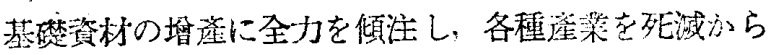

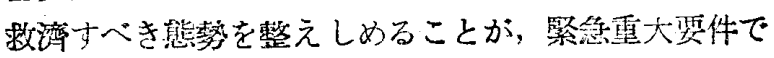
あると信ずるものであります：もちろんこの間におい ても個々の問題に對しては，一刻も婹㐨もなくできる

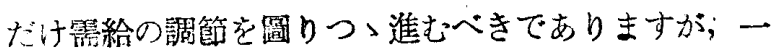
方においてはいま申した綜合的な現状調查は郎時筫行 に移さるべさでると舁います。目下各方面において

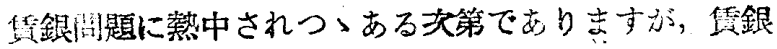
が上扎社能率も向上するから，生産もぐんぐん上ると いう理屈にもなりましようがここの重大なる伦機にお

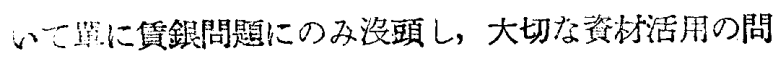

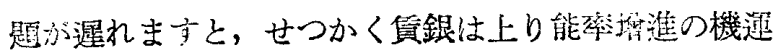
は篮つても，材科枯渴のために肝心の仕事ができなく

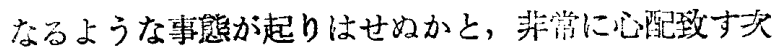
第であります。

穔田幹裋引引續いて吉川晴十さんに御意見をお愿 い致します。

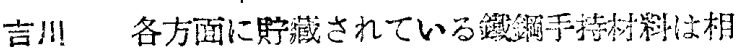
篦多いと照われていたが，筫際調查してみると，あま り澤山はないということであります。中には高速㡽鋼

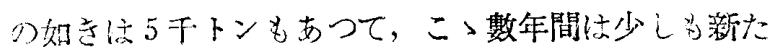
に造らなくてよいというようなタのもあるが，大體に

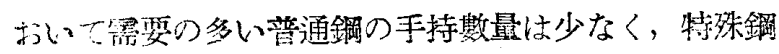
ふ比㙻多いのではないかと䍐いむす。それでこの特

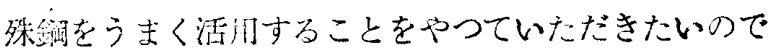

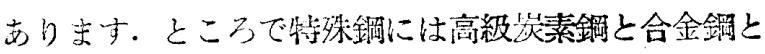

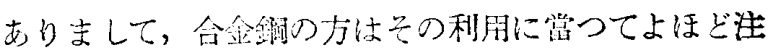
恚をしないと後で目ることができる恐れがあります。 わが國の合金鎆の中にはクロムを含むものが多くあり ますから，これを本宋の目的以外のところへ使えば， 時として使用中に应揨を起すことがあるし，まだれれ がスクラップになつた涝合，之れを使つて造つた鍓つ 性質が琵くなるというような場合も起りう㤂ので范り ます。悡は30 年ほと以前にアメリカのメリーランド

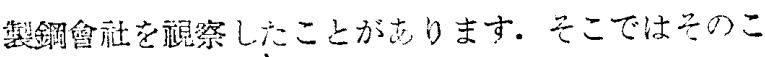

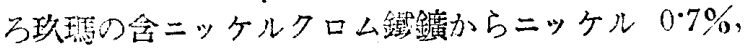

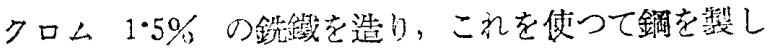
てレールを作つていたが，後にこのレールは使用中に 折えるので留造をやめたという話を聞きました。わが 國でも南洋の念ニッケルクロム鐵鑛を㣀入したことが ありますが，ニッケルやクロムが普通嵞へ混ずるのを

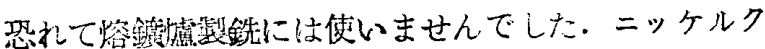
ロムその他の特殊元素は特殊鋼として適當な㪇處理を

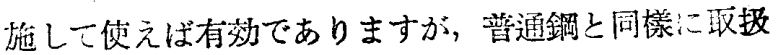
えばかえつて危险であります。鐵道では以前使一てい た珪素マンガン鋁のばねが故障を起しやすいので、素 銅を使うことになつたということは先日大塚さんうら 承りました．鐵道の如きその故障か人命にか力かるけ のにおいては特に安全第一を期するのはもつとまっこ

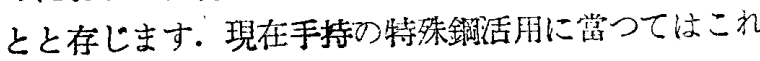
らの點に十分御注意をお愿いしたいものであります。

横田幹事つつぎに鐵道技鯆研究所の川村さんにお 願いします。

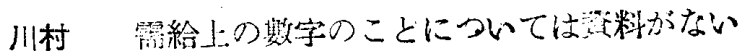
ので电上げられ机が，戦時中つくられた树料をこれか らの本和產業に利用するということについて二，三意 見を申上げす。

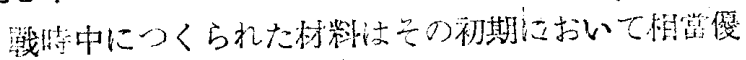

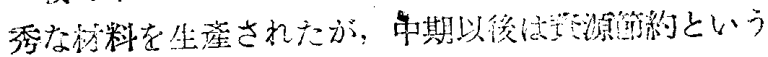

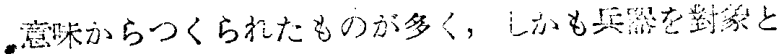

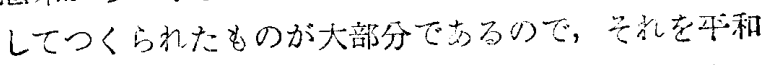
產業に利用するにはいろいろ考虑すべき點がたくさん ある、吉川先生からも括があつたが，たとえば特殊 鋼を利用する場合についても，その利朋する目的が從

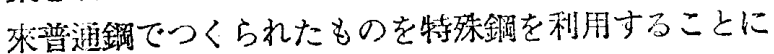
よつてその性能を间上する。古るいは重曋を節約する

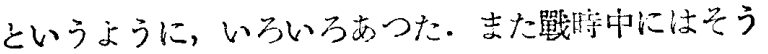
いうものを使いたくても一般的に佼えなかつた。いま はそういうをの法使える。それによつて性能を向上す

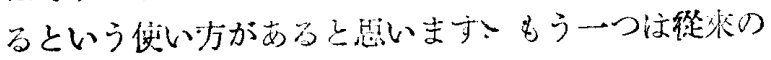
性能を無而して，ある目的に合う材料なれば，かなり

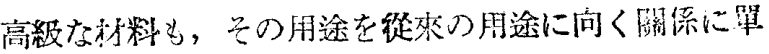

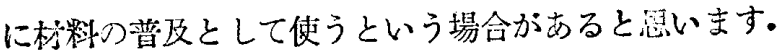


第1の場合であるとたとえば機關車の部品等につ

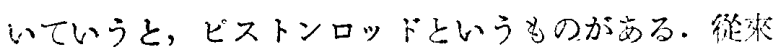
のコーアボンスチール, 先程怙話が出ましたが，10 2，3，4 という材料でやろうとして扔. 性能もカー ボンスチールから見礼ばよいが，まず蔎計においては 小さな寸法にして輕いものにする。并れから磨耗をす るような部分汢これを硬化すると相當な硬度に出るか ら，それによつて部分的に硬化をして行く，そういう ような使い方があると思います。それはいっ諴みであ ると思いますところがそれを實行する上に，瑽來力 一ボンスチールを使つておつたときには，整造過程に 客接が使つてあつたが，そのま〉の工程で移すと愘接 なやらなければならぬ、ところがこの材料はカーボン スチールに比べると熔接は不向きな材料である。また 䟹耗を防く意味から摆入れをすると，硬化された部分 々いろいろの部分がある。材料としては非常に脆いと ころがある.そういうことを考えますと、これ包簡單 にはその硬度が出るからといつて，部分的に硬度させ ることは疑問であることを考えると，この $2 ， 3 ， 4$ を 路來のカーボンスチールを使つて性能を向上するとい うことについても，铻計の方から言つても，作業的な 方から言つてもいろいろ問題がある。そういうことを 上く理解して使いこなした上でなければ，折角い〉目 的に使方うと思つたことが，かえつて惡い結果となる 場合があるか子知れないと思います。

它れから同じ 2，3，4になりますか，これも車䡼の

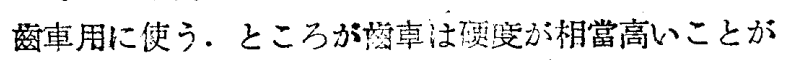

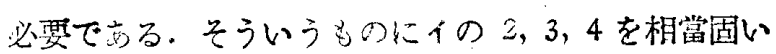
蒸入れをして使うとならとやはりこの材料は硬度の相 黨高いところでは脆い然質を現わすものである。そう いうことであるから，いまの上うなションクを受ける ような部品では相賞管險を現に見られたものもある。

こうなると，設計ならびに㖣材料を使う上の考慮とい うをのを十分にやらないと, 結諭としては炭素鋼より

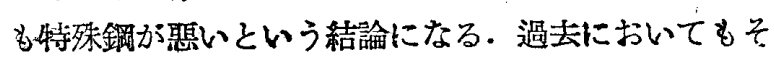
ういうことがあつたが；結論はその途中の必要なもの を考えることを後にして，特殊龬が普通銅よりも琶い 上いう點を斷定を下される心配㹝多分にある。特に先 琵多打話があつたように，そういう閣係の人々にはよ く認識してもろう機會をもつていただここよか必要て 品る。

それから非鐵材科のことについて二，三の點につい て由上げます。輕合金關係は大部分のものが非常に優 秀な性能を持つておつたのでありますがややはり戰爭 中ばを過ぎると，地金の附雷，地金の污れ方というこ 上によつて，だんだん純粹な材料だけではやつていけ るくなつて，いろいろ代用材が出て參りました。この 代用材でも遺感ながら規格性のある材料を使うことは 兒狀においてはできないと思いますが，しかし特にと

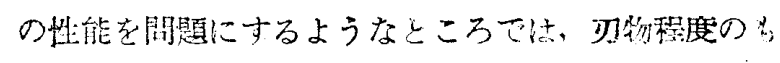
のを使わなければならぬと琹い志す。

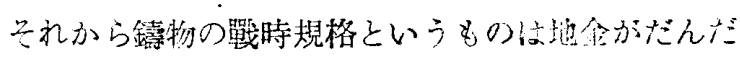

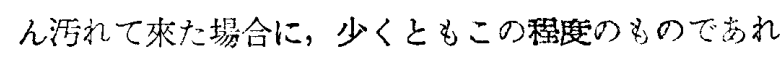
ばまず贸求に合うものであると思いますので，穴うい う特殊機䂝，自動車をおやりになる方は御參考にしい いたっきたいと思います：

またアルミニウムは今日では生座を吘されないので ありますが，ある時期になればあるいは輸入ができる かと思いまず。そういう場合に折角い》地金がある程 序榆入ができても，それをボッにしてしまうのは申譯 ないのでありますから，せぬて戰時規格程度の規格性 をもち，性能を獨占して使わせて行くという珯準備が いっのではないかと思います。

それからニッケルの代用銅としては，銑鐦がだいた い終践前における代用電熱鎆上なつたのであるが，な お最後にできたものは窒素を入れた窒素含有の八イ・

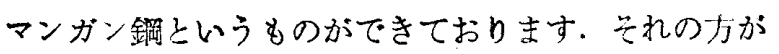
單一些能ははるかによいということになつております。

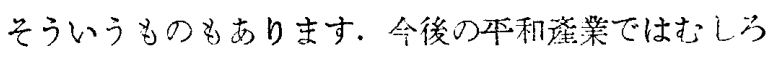
從來より为高級なものを使つて特柇の目的を澾すると いうことも必要であると照いますので，ちょつと申匕 げたわけであります。

横田幹事一般的問題について御餐見の御發表が ありましたから輀要者側の御意見を承りたいと思いま す.まず連灀省の大塚誠之さんにお願いいたします。

大榢 今日は皆さんの拉落承りに上りましてい ろいろ参考になることをききたいと忽つております。 御指名に預かりましたので私の方の事情なり希觜なり を申上げたいと舁います。

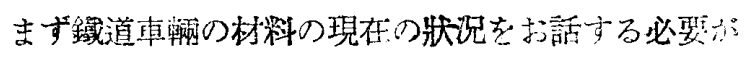

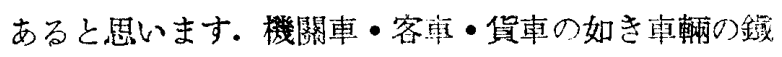

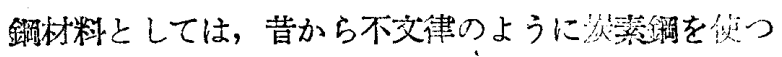
て招ります。昭和に入つて特殊鉬のいるいろ優秀なも のができるようになり，また处國から旅入その他によ つて特殊鋼が獲得できるようになつて來たのですが， われわれの方の䰺持としてあくまで炭素銅で行く，以 殊鋼江使わないという建前をとつて來たのであります。 その原因はいろいろあるが，主なものをあげると特㲛 錩はあまり上等なるのはなかつた。また貿的に韭裳に

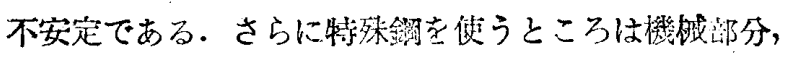
特に磨䞔の激しいところへ使わなけ扎な゙ならないと思 いますが，そういうところはつねにわれわれの片の工 場で神修をして行かなければならない：方するるそ

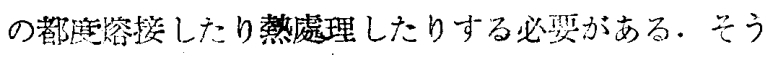

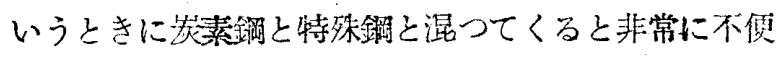

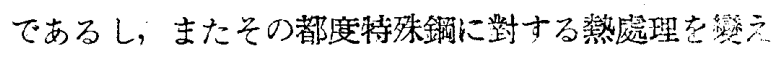
るということ夕，ほとんど不可能である，以上のうう

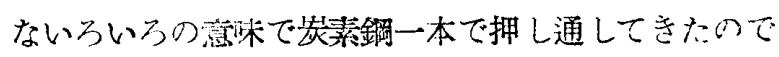




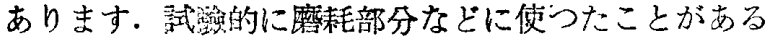
が，失敗に終つております。たとえば機關車のピスト

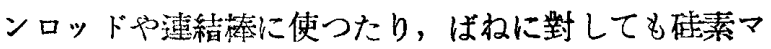
ンガン鋼を浐つてみたりしたが，一つとしてょいもの はなかつた。しかし現在としては戰時中淮步しな特殊 鎆の技街を何とかして車輛に取入れてやつていきたい という考えから，またちよいちよい使い始めて乱りま す、焚としても成功したい念願をむつて扔ります。 ちつん最近においても十二失敗を繰返しておりますが，

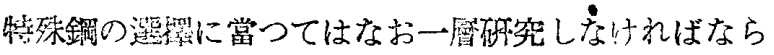
ないと䍐つております，特に鐵道は人命を頂つておる ので，ただ試驗的によいというだけでは优えないので す．兵器のごときは一庋使えば廢裹してしむえばよい が，鐵道龺樰は長いのは 40 年，50 年，短かくても 30 年は使わなければならない。その間いろいろ修繥 をする。そういうことを考えますと，私自身としては 特殊鑃は使いたいのですが，この代用材程度の，戰時

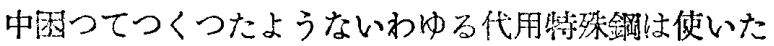

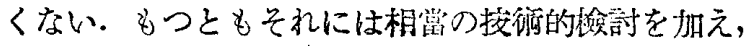

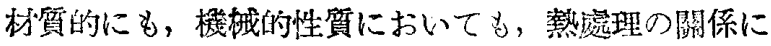
おいても韭常に安定性のあるものは别であり安す。

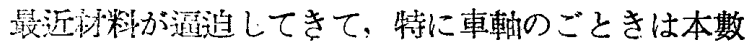

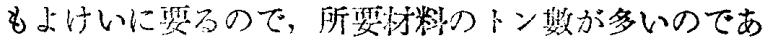
ります。この東軸に對してある會峿に打いてけクロム マンガン鋼を使わしてくれというところがありますが，

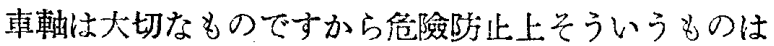
なるべく避けていきたいと栄えております，要するに

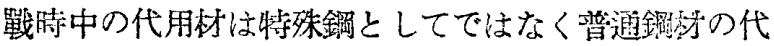
用础喓に使いたいという程要に考えております。特殊 鍕の製作會社におかれてもつと筫驗なり，あるいは製 品の安定性なりを如賽に示していただければ，むつかか しいところにも使うことができるが，そうでない以上 戊えないと慙います。

それから戰時中に製作された材料等非常に不良品が 多、のですが，インゴットの步留りにおいても，非常 に大きくとつている工場が相當多かつたのではないか

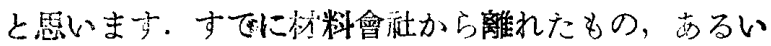

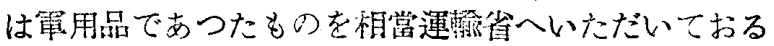

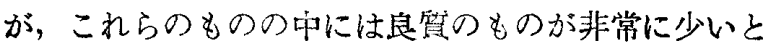

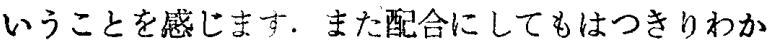
つているものが少い.

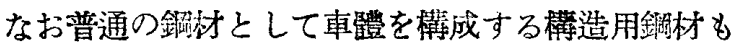
使つておりますが，これは現在の普通の炭素鏹をなる ベくやめて，まう少しマンガンを多く含んでいるもの

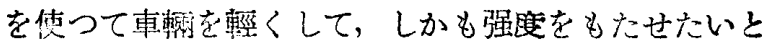
洘之一方ります。この材料はアメリカにおいては大分 以前よりコールテン等つ名前で使つています。なお鋼 材にしても，特殊鍓にしてもわれわれの方でどの程㜔 にビのような烣粼かるかということがわからない。
これをストックしておるところは，これらの枋料をた だ何とかなるだろうというので曼然と持つておつて， 㮩極的にどうするということを考えておらないと䍐う のであります．最沂になつて何とかしようしいう摖持 になつておりますが，こういうものをすつかり明るみ に出してやるように，この際特に正確な統計を出して むらつて，一般に公表していただければありがたいり 思います。

つぎにアルミニウム㟓るいはアルミニウム合金を鐵 道方面に使うことを䃑究いたし，陚作の意味で客真， 電車数量を宽成し配車致しており末す. 客車は黑く整 つてあるが電車は㴽明ラッカーで望つてあります。 れらの本外外部の板にもジュラルミンを俌つています ので長年月の閜には筷玲の問题が起方と思われきす。

アルミニウムのキャステンクの問题でありますが， 內部に使う金具類はできるだけアルミニウムまたは子 の合金のキャステングまたはダイキャステングに變更 して工事をやつて拈ります。そして車唡を輕くして石 炭の節約ならびに速演の品上を評りたいと考えており ます。

なおアスベストも機閵車には相管使いますが，知瀻 維のものを確得して，使用中の喪繢維のものに混ぜて 使つています。最近石岑不足から宕綿がつくれなくな つてきました。これは冷藏車の断熱材料に使つていま すがここれができないために冷藏車ができないで困つ ています、その㴽いろいろありますがこのくらいに しておきます。

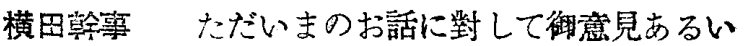
は御曋問がこささいませんか。

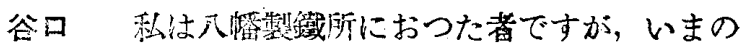
アスペストの件につきまして，すでに衔承知と思いま

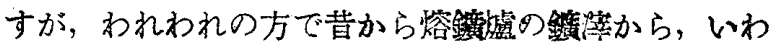
ゆる鑛㳯綿を大量逝つております。これは普通の岩綿 とくらべて多少の相異はありますが，特に保篹とか微 熱とかいう點についてはま寸゙損臽なく，殊に高温にお いては㷋來の岩䄸よりも一磨有効であるという試驗結 果出ておるわけですから，今後こういう方西に磉力 御使用愿えるば，お役に立ちはせぬかと思います。

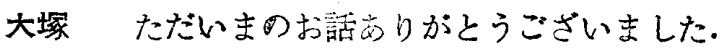
アスベストの短瀻維のものでできるかと申されました が，アスベストではちよつとうまくいかない，殊に短 繊維のものではうまくいかないのでありまして，やは り相當のエヤ・ポケットをもつた岩綿式のものでなけ

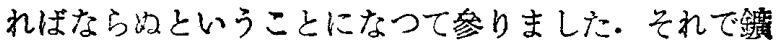
涬綿が岩綿とだいたい同じような機能をもつておるな らば师常に都合よいのですが，令叟泣々礼を一つの形

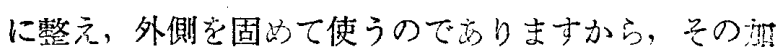

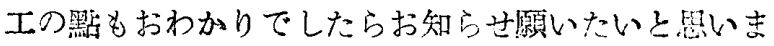
t. 
谷口十分野究しまして，只ういうふうに御趣旨 に舅うようにやつていきたいと罢います。

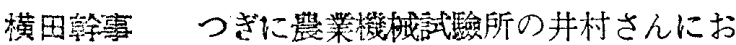
話志承りたいと罢います。

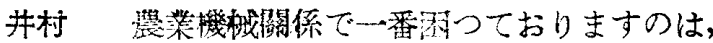

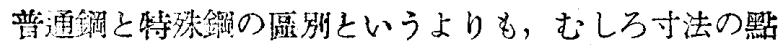
でかります。たたいまでは鑘材を持てあましておるか ら，これを一般の需朋间に出すというならば結棈なの ですが，そういうことはなかなかむつかしい，それで これをある機關によつて適正な寸法になおすがよいと 思います。これには幸いに，厢延彗者としては，石炭 さえ入手ができればいつでも再檿延するという意向で ありますが，石炭の沲教汢わずか鋼材トン當り 400 キ 口乃至 800 キロくらいでありますが，それがゆきわた らないために厴延ができない，光のために相當の數量 がこういう事情にあります，現時の資材の危機を切り 拔けるた的には，ほかの方です多分に同樣つ事情にあ ろうと思いますから，とりあえずこういう寸法のもの を再激延して，小さいものと薄い多つになおす。これ

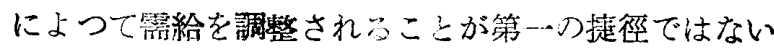
かと洘えておる夷第であります。

日本の再趡のために必要な鍓材は寸法から見ていろ

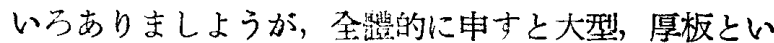
うのは少く一部分に限られてそのほかの大部分は中 型・小型・灌欲ではないかと思います。それがいまま では一番敘如しておるので，まずこの寸法をそういう ふうに現在あるものからなおして，それから今变使用

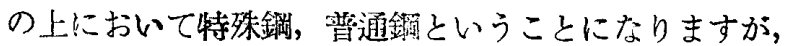
これは潘材通所に使うということは一番望ましいこと ですが，これはむづかしいのであります，归に使われ ておる状態を見ると，特殊堸の方ではこれを調べて見

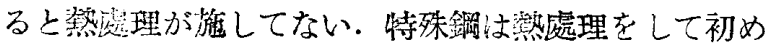
て效力を發するので，加工し放しではそ效力を發し

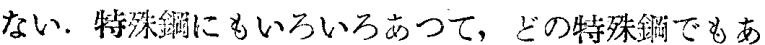
らゆる用途にすぐに值えるということができないもの もありますが，大部分はその使用よろしきを得れ状效 力を發することは街知の通りであります。それで熱

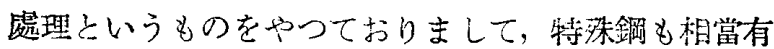
効に利用できることは間遗いないのですが，ただ閳題

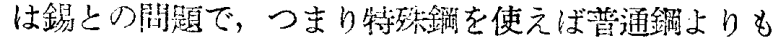
力为衙久力もあるということでありますが，どちらか といえ菭，小さな材棹で大きな材料に置き換えるとい う方に倪くのではないかと琹います。どうしても大き なものはこ礼をある、法になおさなければならない。 そこで少いうもののある在り場所をはつきりして，

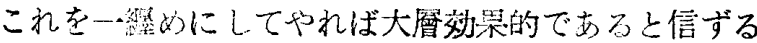

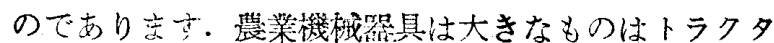
一から，小さいものはクワ，力マというふうに筑囯が 非常に庴いのであります。この所要の鋼材に對し私の

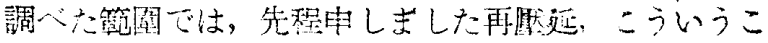

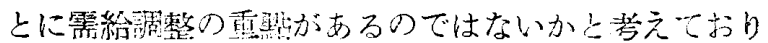
ます。

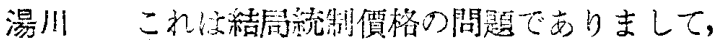

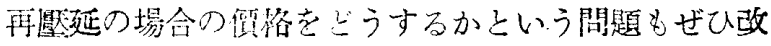
訂していなだかな汁ればならないと思います。製鐵會 社にある愿板を薄く引延ばして潘るというときには， 再曆延ということはあるいはいつ得るかも知れません。

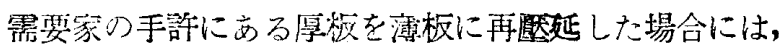
やはり賽要家の方から一隹薄板を欲しい需要家の方に 話をつければ簡暺にいきますが，薄板の價格で取引せ ねばなら收となると，原延引不可能ということになる ので，その邊のことはこの委員會で御矿究を願いたい と思います。

井村 Wま电上げましたのは，もちろん穓加工の 場合だけしか考えておりません．製造業者の手持ちの 厚いもの，あるいは大きなむのを即嘪用として堅延さ れるということまでは洘えていないのであります。需 要者側の手持の厚いものを血延することであります。

したがつてこれは䝿加工になります。

横田幹豪化學機械學會の宮崎さんにお願いいた します。

宮崎私別段に考えをもつておりませんが，設計 方面つことについて御意見を申上げたいと思います。

い主鐵材がなかなか不足しております。生產方面の 䨋要の1割くらいしかないとかいわれております。そ れで大䜾は自分の會䩜のストックを利用して製造しな ければならないという工合に，設計を十分にきりつめ た材料を使わない設計の袎械を造らなければならない ということは當然であります、けれども，なかなかこ の設計を强度一つぱいにきりつめるということは，よ ほと優秀な技菦家でない限りはできない，聳來われわ れの工場でも，どうも設計者はとかく安全率を餘計取 りたが，そうすれば機䂝の故障が少いから，結局丈 夫な機械を浩つておる.こういう時代になつてくると， そういう設計は許されない。できるだけきりつめた設 計をしなければならない。

だいたい私共のやつておるのは化學工業用の機㭜で すが，化學工柴用機䄾はだいたいが大きな設備の，大 きなタンクの中で，化學樂品などが堂つ㸚られておる。 あるいは化學反隹の如きものを起しておる，そういう 操作のものが多いので大きな器が澤山造られて㧍らの

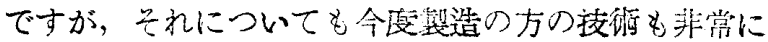
考えなくてはならない.同じような化學反應をタンク の中で起すにしても，能率のよい，非常に反應方早く 起るというような優秀な設評をしなければならない。 從來はがつちりした必要以上に大きなるのを榄䛠して 行く傾向にあつふが，それではいけない。できるだけ 早く，できるだけ材料の少い器の中で反照起させる⿸ 


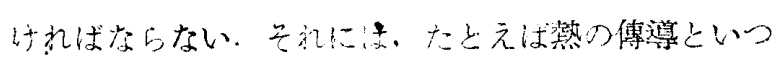

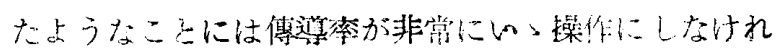

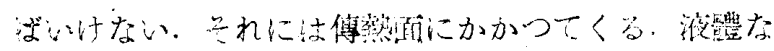

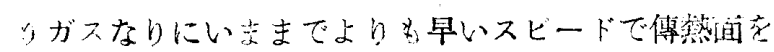
通過するというようなこと，非常に速度妾早くして熱 が傮わるというような設計を职於なければなるない。 それにはあるいは温度高めるとか，ポンプの萑蹬を 早く偱環させるというような操作が必要になつてくる. 一方においては，たとえば宾ポンプのような字ので， いままでよりも能のいいすのを造らなければならな い，六にには私の考えですか，つまり機諓の何轉速度 を早めるということが機械の大きさを小さくするこ ういつたようなことに對しては，つぎにすぐくるのは 軸受の開題です，球軸受はいままで二つのところを， 今段は之れが十分に便えない，普通の軸受でその代り をさせなければならないというようなこと、名れから 可輏が早くなるにしたがつて，軸なじがいままでより

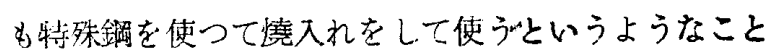
になつてくるのではないかと思う。ところが材料の處 理、いろいろの熱處理というようなことは、とうるい ままでわ設計萧の方では考えに入れないようてありま

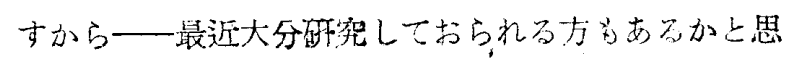

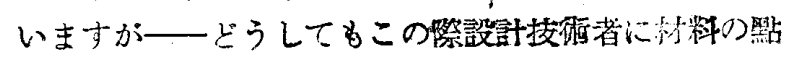
に教する再教育をしなければ，できるだけ材料孛儉制 して，强度一ばいの設計をして貫うということは非常 にむづかしいのではないかと思います，その點材料り

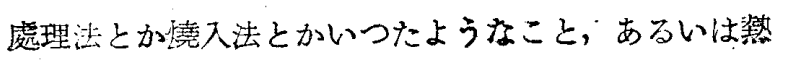
の愹接法とかいうようなことを實際問題についてもう

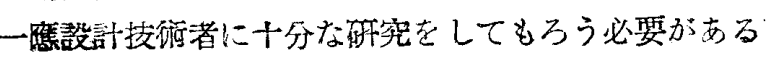
のではないかと考えております。これらは言うへくし てなかなか行われないのでむつかしいかと思いますが， 熱處理法などの實地の再教育の機關ができたら非常に いつのではないかと考えます。

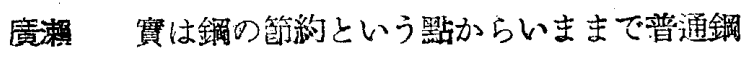
を使つて抢るところに特殊鋼を使つて戴くということ が非常に大事ではないかと一般的に考えておるのであ りますが，先程もなるへく䈐素鋼を使うというような お話がありますので，たとえばばね堸というようなも のは從來汪とんど炭素銅を使つておら礼るようであり ますけれども，1 232，1．234 とかいうようなマン ガンをばね鋼にお使いになるということは，結局こう いう遊休資材が有效に活用する一つの方法ではないか と思います。すでに製品になつておるものが多いので ありますが，先程井村さんや湯!!さんの方から括の 再硻延という問題が方こに出てくるのでありますが， 幸い相當鋼塊上か鋮片とか子あるようですから，そう いうような方面に利用して戴くことがいつのではない

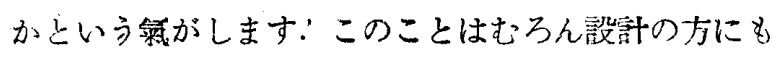
關係があり，特殊鋼を使えばむろん量が少くて濟む。

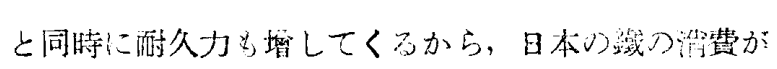
減つてくるというこ上に鼠なると思います。これか。 らの日大はじして最を期待できないから，留の方 を上げて䁷減らしていくというふうに隼まなけれは

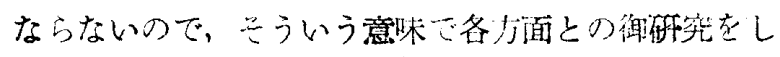
て戴いたらとうかという带がいたします。

それから步一つは、たたいま東上げたのとは全然 逆なことでありますが，窒化鎉のような文のは，これ が窑化鍶として實際使われ、ばそれに趋したことはな いのでありますか，いま窒化鍊を使うような用涂沬あ るいは見當らないかも知れない。これもいるいるの關 係があつて，何でも使うというわけにはいかないつで

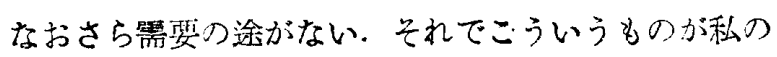

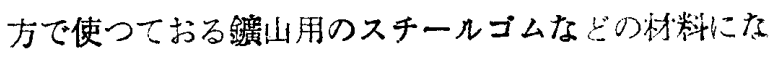
らないかということを考えたのでありますがこれは どうも非常にいっスチールをなんでもい〉ようなお。 に使うので，材籍からゆく非常になさけない，ある いは虐代されるようなことであるか知れませんが， 汪かに使途があまりなくて，材料が菬山ストックされ。 ておるとすれば，その點からでするるいはこういうこ とも已もを得ないことである。殊に米し只ういうふう

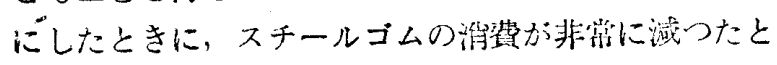
いうこ上があるならば，また，々の片直で派にお役 に立つておるのではないかという舞がするのでありま す.

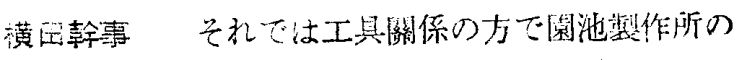
佐藤さんにお激いしむす。

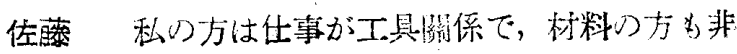
常に限られておつて，大して御參考にならない上思い

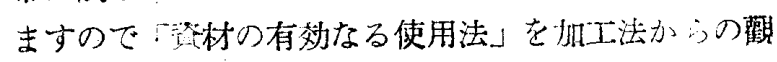

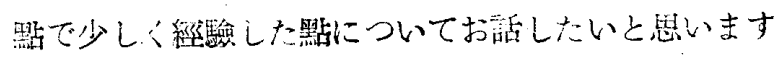

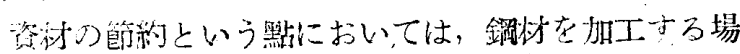
合、切虭工具艾使えばきり粉がで。このきり粉にな

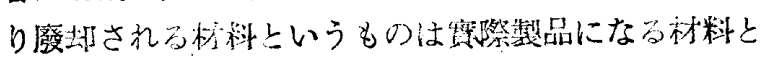

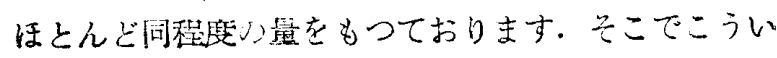
うきり粉を出さぬ加工法を考え扎ばよい: 一般们にい うと冷間加工一機栈加工に朎間加工を篗用寸ること によつて相當材料を節約できるのではないか。たとえ

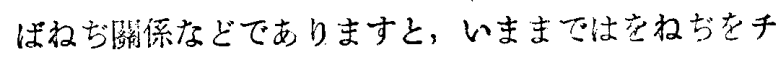
ェーザーかダイスとかできつておりますがこれ苯ロー リングダイスでもり上げて作つた場合賞然きり粉が出 ず材料が節和されますし，てれからこの轉造法によれ

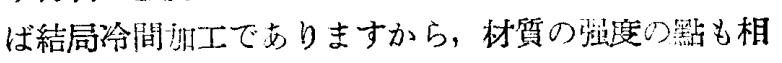

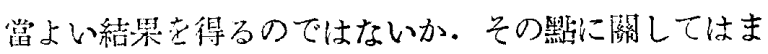

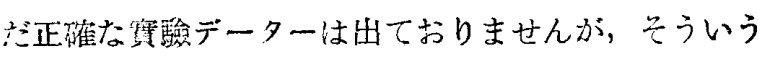
加工法から相當の材料の節約を促進させることができ ると舁います。

そう一つは熱處理上の方法であります。すなわち高 周波豦入苍使用することによつていま問題が出ました 


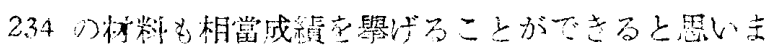

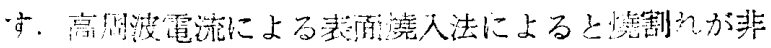

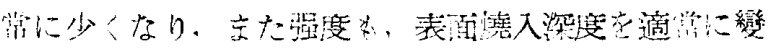

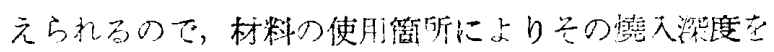

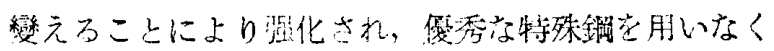

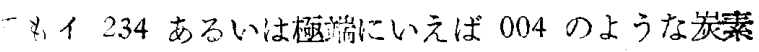

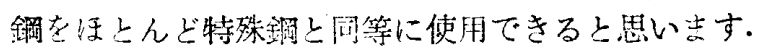
これは終戰前まで京都の鳥盖愽士のところて高周波宽 入れをしばらく䃏究していたので，その上きいろいろ の閏題を技つた經驗少ら申上げるのであります。結局 ザ材を節約するということは加工法に再检討を加える 必赑があるのではないかと考えるのであります。

横田幹事私から一つ持ね电上げます，豁接鋼 は最近修縒や資材の節的という方湎から相當多量に要 求されてくる傾问にありますが，熔接棒の心缐の製造

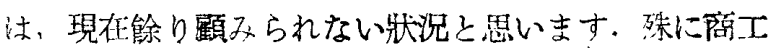

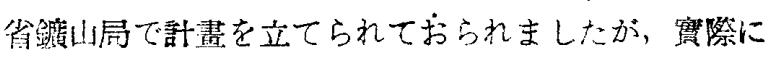
は一向に整造されず，配給救全くないそうですります。

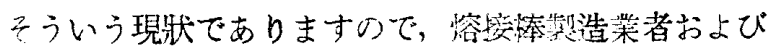
各丁場においては，あり合せの材制，才なわちストッ フ使つておいでになる。これの中にはいつの市りり

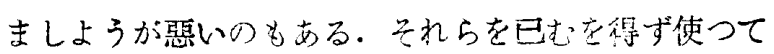

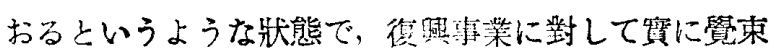

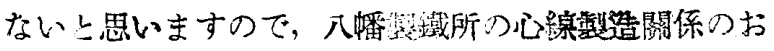
話苦承りたいと思います。

湯川ただい主横田さんの方から熔接棒の心線の 慗造について八璠のうはどうかというお話がこさいま した。八幡におきまして心緗を造る設䚚としては，ま ず鋼を造り，そわを線材に延ばすというところまでを

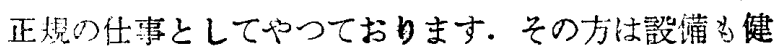

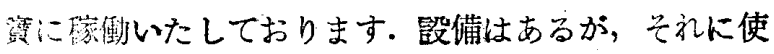

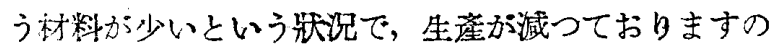
を，客接棒の心線としての指示と申しますか，商工省 の方から熔接線材をいくら造れという指示が來ており まして，そういうところで新らしくできますものもか なりあるのであります。

それからなお焀接線材の製品の問題について一言申 上げたいと思います。ただいまでは內地の石炭を用い

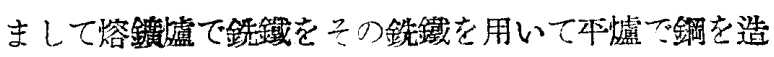
り線状を造つておる關係から，之の成分の中に相賞程

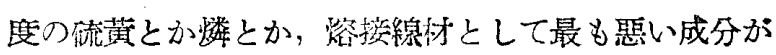
かなり人つてくるので，それを除去するためには非常

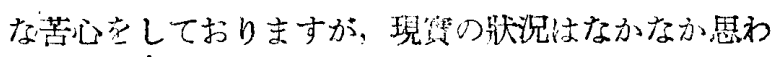
しくなく、アメリカで使われておるような䟽武と燐が

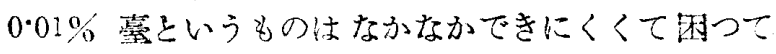
扣ります、日本の規格は 0.04 以下となつております ので，極力只れに到澾すべく努力はいたしており志す。 要するに鐵全䡞の生產量が殖えない以上は愹接緗材ば かりやるわけにはゆきませんので，その琵惡しからず

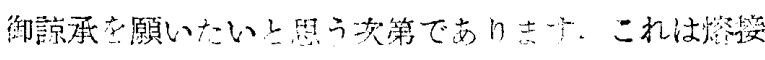

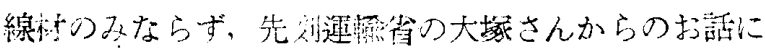

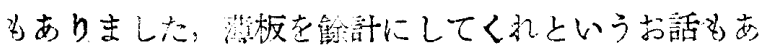
りましたが，これ为亩栐でありまして，全娟の量が殖 えてくれば，それたけ狳計造れるということにはるか

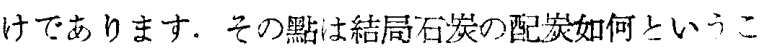
とになつてきます。鐵を大量抢使い願つて抢ります墔 械關係の方々に對しまして非常に虫譯ない事態になつ

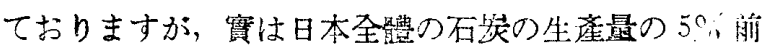

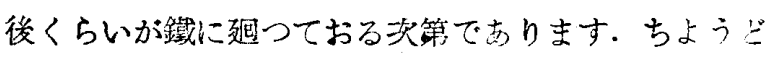
昭和 10 年ころが 12\%，18 年が $23 \%$ が鐵に䞴つて おりますそそれがただいまでは石炭，銑堸超重觜生捱 計書にて $8.5 \%$ に改訂されることになり $8.5 \%$ の唒篇 計畫が決定しました最近までは5\%そこそこす配炭に なつており，現賽にはもつと下つておる次第であ引ま す.それで石炭が㭵つてくるようになりますれば灀力 生產も殖やしたく思つていますし，また生產の種頑む，

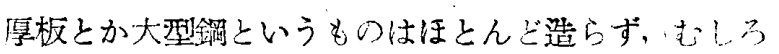
紐くて薄いもの，すなわち線材のような細いもっのとか， あるいは薄板ということに集中して生產いたしたいる 洘えております。

横田幹事 いまのお話で莫然とわかつたようであ りをすが，從來む熔接棒心緗の方は量の䦗題で八幡で は浩れないのたという話を聞いております。というの は多少資材が超つて來ても，心線の方の量が整鐡所刀 全般の工場に對して非常に微々たるるのである。だか

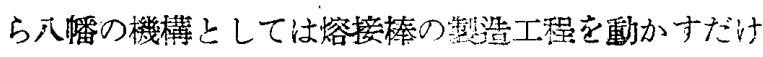
の仕事にならないということを伺つておるのですが、 その點いかがてすか。

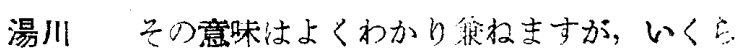
少いといつても，10トンや 20 トンの數字ではないる

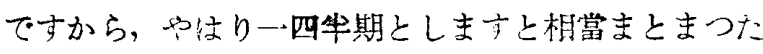
數字になつておりますから，平㠠を㖶子すにして多や

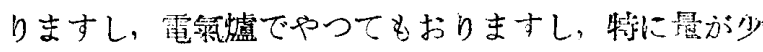
な過きてできなというよりも，全體が隇つて扔るか ら結局少くなる上いうここではないかと思いむす。

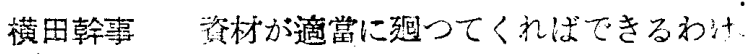
ですね.

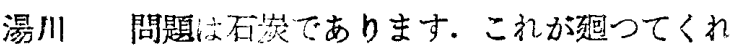
ばできるわけであります。生産割當が品種别にずつと 出ておりますので，穴の中に織込んでゆけるわけであ ります。

横田幹事 ただいままでの御意見で特殊鋼つ利有 についで御意見の量つたところがこさいました。これ に對して一般的にもう少し御意見を伺つたらどうかと 琶いますそれに對して王置さんにお願いしたいと思 います。

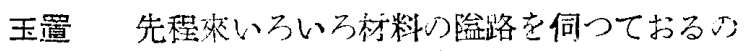

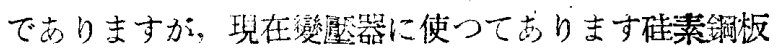




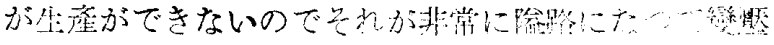
器ができないということを聞いております．硅素銅板 は私のところでは造つておりりせんので，現在ごうい う鼠態になつておりますか侗いたいと思います。

湯川!最近各方面から硅素銦板を造れという御命 令法韭常に澤山ありまして，八幡では全力を趡してこ れの整滔に努力しております，硅素鋼板には大别して，

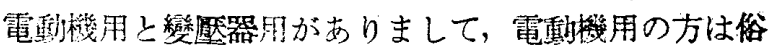

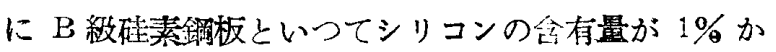
$1.5 \%$ 內外というところでありますが，トランスフ

オーマーの方は 3.8 から 4.2\% のシリコンがはい ております、そのようなわけで，たいたいこれを造る には電氣譃でやつております，ところが八幡の方む終 戰當時は電氣爈を 4 基乃至 5 基動かしておりまして， 21 年夏㥧まではだいたいうまくいつておりましたが

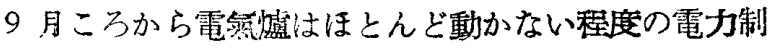

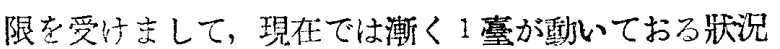
であります。この電力飢饉が解消せぬ以上はなかなか

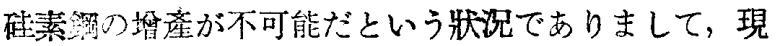

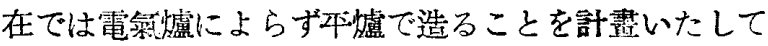
おります。從來も本㠠で造りましたが，これはシリコ ンの含有量の少いものなら平㠠でできます。これも從 來は固定平㠠では非常にむつかしいので傾注式の本㠠 を使つておりましたがいまのところは動いていません． というのは石炭不足のためにガスが不足する，八幡の 傾注式はガスで動くようになつておる關係から發生爈 が使えないというわけで困つております。これを䋃か しますと今度は $\mathrm{T}$ 級もそれで造ることができる。こ

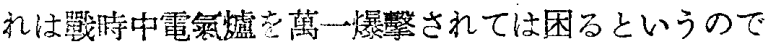

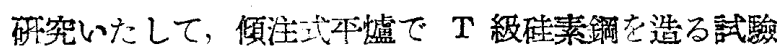
を完了いたしておらりすので，今度はその傾拄式を動 かそうということを考えまして，その精鎠用の重油を

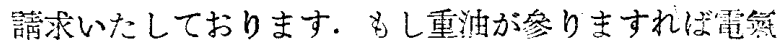
爈を休止して傾注式の多爈で硅素鋼を造れるというこ とになり，量羊餘計できるということで相賞仍究して おります。しかし重油が參りますまでは如何と仕方

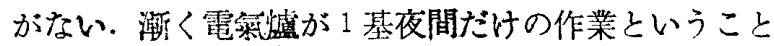
でこれまた各方面に非常に御迷惑をかけて恐維に存 ずる次第であります。

石田要員＼cjkstart私のところでもイ 232 とか，1 234 と いう材料をもつておりますが，この活用一覽表にばね に渎うとありますが，普通のカーボンスチールの場合 こ苏るいは硅素マンガンのばね鋼に比較してどのくら いの䢩いがするものでしようか。

守屋々れは賽際實羷してみたのではありません で，およそこの性質的らみて，こういうものにも使え 汇せ放だろうかという程度で志ります。

湯川 特殊鎵の問題について手持在庫の活用とい

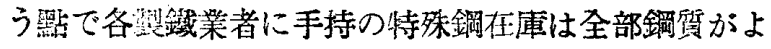

く乵わかりになつておると思うので支ります，嚄陸海

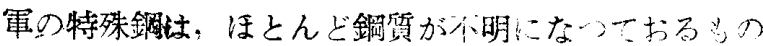

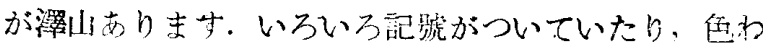

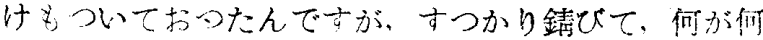

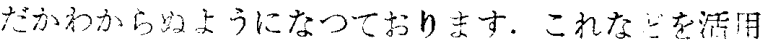

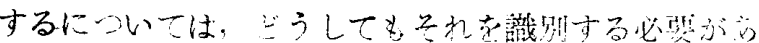

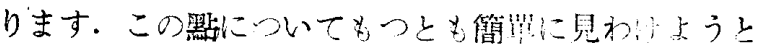
いうのがーつの問輗だろうと思います。この簡單なう 法として，火花によつて材質が相當はつきりわかりま すから，そういう方法もとれるのではないかと思いま す. 明磨盤にちよつとかけると火花が出ます。号の長 さ，形狀によつてわかります，成分が道いますと長さ， 火花の狀泟が違うという所で見わけがつけられますが， そういう方法でやつて戴かなければならんのではな いかと思つております。そんなことをこの委員會にお いて標準を造られ，各需要家に御指示頋えば非常に幸 いだと存します。

大塚 ただいまのお話ごつともと思います。た だ特殊鐝を使う場合には相當大事なところに使うわけ でありますので，火花試驗程度ではちよつともの足ら ないような举がします。何かもつといっ方法があつた らそういう方法をこの委員會に一つお願いしたい上思 います。

乞れから先程三聴さんから運輸省はばねに装素銅を 使つてするが特椋鋪を使つた方が材料の節約になると いうお話があましたが，なるほざ特殊鍓を使つた方 が材料の節約にもなり，また長持すれば々れだけ材料 の節約になることはよくわかつておりますが，ただ賽 際使つた場合にまだ使用實績というタのがはつきりし て抢りません．特殊鋼の整作行程から洘えてみますと 現在の製作方法てはなかなか良質のものができないか と思います。まず特硳煌素がはいるので溶解鑄造の作 業が非常にむづかしい，それから屏延前の切り取りの 問題がはいつてくるだろうと思います。そういうよう なものを綜合して，ただ單なる！䇫 2 筬の試羷片で なく，10トン答解するならばその 10 トンから何トン かのばねが出て參ります。冬のすべてのばねに對して、 綜合的な機械的性質を調へ，この材質のものはなるは

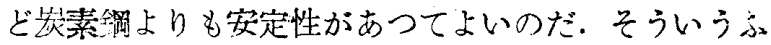
うな何らかの試䮡結果が必要ではないかと思います。 ある會社のものは非常に優秀であるが他の會社のもの はよく折れるということになると，どうも材質が全般 的に信用できないということになつてきます。吕こで ばねに適當な材料を取つて戴き，その機㭜的情留はか ういうものである。紫造上にはこういう注意さえすれ ば攺全であるというようなことを委員會のうで御指示 下されば非常にいこことだと思います。

石田硅素マンガン鋼のばね材料つことを調べた ことがありますから車上ぼるのですが，カーボン・ス 


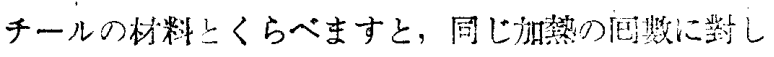

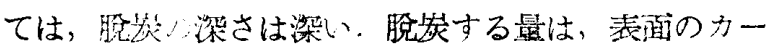
ボンの㻎わ少くなるのでありますが，蓮輸省の板ばね のように繰返し憢きなおしては組立て，何可も繰泛し

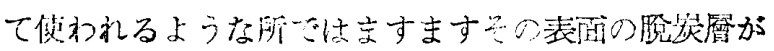

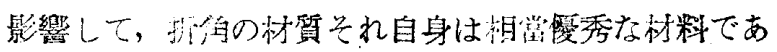

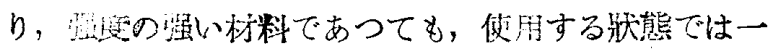

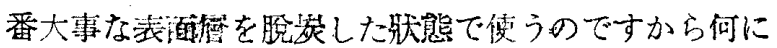
も役に立た次というような幵になるだろうと思います。

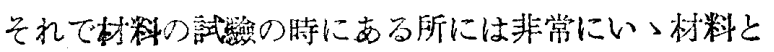
して現われ，ある所では非常に惡いものとして現われ るということのあることは絬局それだろうと思います。 しかし繰返しそういう加熱をしないばねのようなもの であれば，之れは材質自宥の性筫が割合に多く現われ

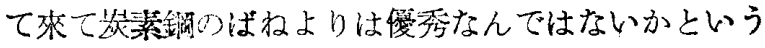

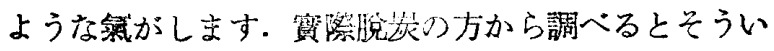
う結果になつて參ります。

大塚たただまの話御もつともと存じます。そ の當時つ䩓驗結喿，これは牛實驗室的の試驗結果であ り立か，その結果によるとつぎのようであります。

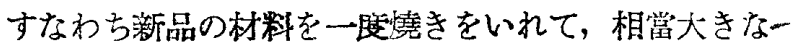
實物に近い試㯺品を造り，特殊な繰返し試驗機によつ

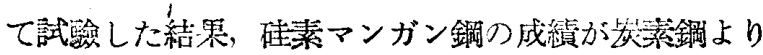
非常に惡い。これはいまの脫炭う問題もありますが， さらにもう一つ鋦の生れつきの問題もあるのではない だろうかとうことを考えましてその線に沿つていろ いら試驗しました。しかしそれについてはよい結諭を 得ませんでしてまことに残念でした。もちろんその場 合の强度は相當出ておりますし材質も相當優秀なよう に然われましたが，何分にも繰返しに矿えないのであ ります。

石田 生れの臨いやつはなかなかなおらぬという ことは硅素マンガンにたしかにありまして，板ばねの 目玉をはげて落ちるときに割れがはいつてしようがな い.ある板ばねのものは少しも割れがはいらぬし，あ る板ぱねの目玉の外側には割れがはいつてしようがは い. その原因はどうしてもわからない，現在でもまだ はつきりしないのですが，そういうものはたしかにあ るようであります。

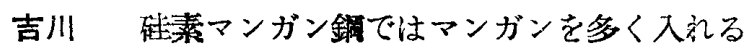
から韭金屬介在物が多くなり勝方ではないかと思いま す.だから表酒厥炭がくても大军さんのお話のよう な惡い成漬を示す場合もあり得ることと考えます。

空共 鐵鋼のスクラップのだいたいの化學成分を 迅速に知りたい，それには灭花訊羷はどうも十分でな いように焽うというようなお話もありましたが，戰等

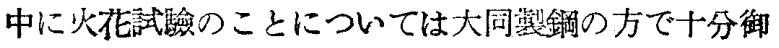
研究をなさいまして，請習會もあつたようです，その 當特私は住友におりましたか，任友の方からもその講

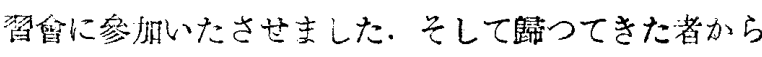
いろいろ話を聞き，またその雇員を中心として筫㥜を いたしまして，だいたいそれを兾地に隹用して便利を

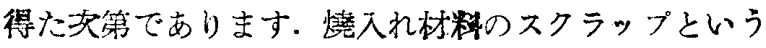
のもやはり單時中にできたものですから，たいたい戰 時中の航空機の材料でできたとか，あるいは陸源军の 我行機のものでできたものが多いだろうと思いますか ら，火花試驗で上手に活用したらだたいの成分の見 當がつくんではないかというような氣がいたします。

それからなお火花試驗と同じような目的で試驗する

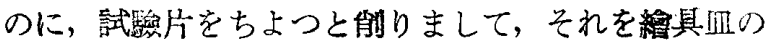
ようなもの>中にいれ，それを酸で溶かして，之れぞ

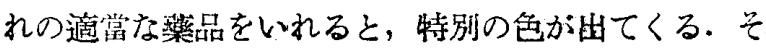
の色の出工合によつてどういうニッケルを含んでおる とか，クロムを含んでおるとか，いないとかいうよう なだいたいの見當を簡易につけるということを神製

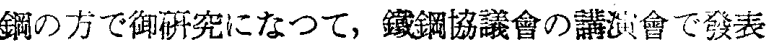
されたことがあります。そういう方法も役に立つだろ うと媤います。

それからなおこれは普通の化學分析でありますが， 鋼を溶解中に迅速に分析をして，そうして溶鹏の涂中 で溶解つ方釬をどういうふうに立てるかということが

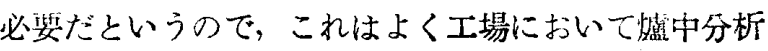
とか，あるいは盛內分析とかいうことをいたしでおり ますが，そういうような目的に䜤するために，もと日 本學術城與會の裂鋿小委䝿會の方で數年前から協间で 碷究をいたし，こういう方法がよかろうというものを だいたいまとめたものが4年ほど前に初版が出ました が，その後さらに改庭した結果をまとめまして，21年 10月ころに第2 版を丸善から出しました。これもだい たいり化學成分を迅速に分析するというのにはお役に 立つだらうと思います。御參考になれば結棈だと思い ます。

佐藤 (隆憛) 私共の方でもいま枋料の入手に林難 をしておりまして，また入手できても先程のお話のよ うに，材質が非常に混つてはいつておる場合がありま すので，どうしても1 本 1 本訊驗したいのですが， 起笔力による判別方法，その他につきお知らせ願いた いと思います。

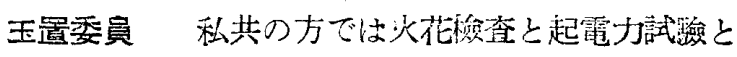
兩方を僧用しております：イ 232 とかイ 234 とかいう ことになりますと，成分が同じでただその分量が少し ばかり暈うという差だ沃では明確な判定がむづかしい。 そうかといつていろいろ試蔡法とかほかの力法いろい ろ合わせてやるとなると, 結局化學分析の方が早いと

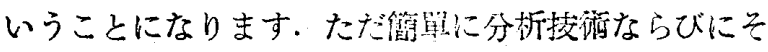

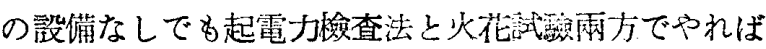
だいたい見當がつきます。成分の㟟なる場合には明湤

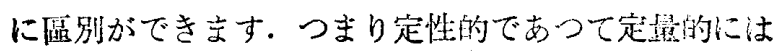




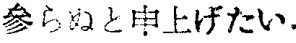

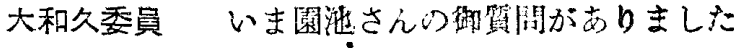
が，八イスで女りますれば，一種から阿種までは畞浑

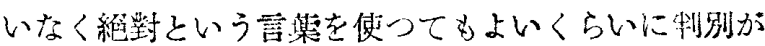
できます。もともと私の方でエレクトロン・モール ト・ピーストを何とか活用したいと思いましたが，こ

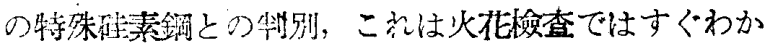
ると思います。ですからそれで四别する。しかる後に 八イスであつたならば，これが第何種に屬するという ことは電力によつてやればよくわかります。

守屋私の所では䠆造が主でありまして，特殊銅 のようなものはあまり使用しておりませんが，八幡か

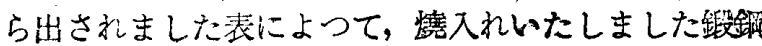
ロールを非常に澤山使用しておるのでありますがこ 〉に出ておりますイ501の成分のものが度適䈏して おりまして，利肘することかできるというふうに溚え ております，伺います之，寸法は 300 ミリくらいまで 堅延材かする方うでして，これから取りますと，普通 よく使う充電池の龂入れなどに取れるように舁われま す。それからこれは銅戈などと同嵄でありますか，終

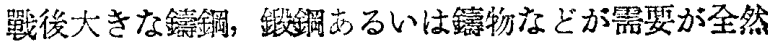
なくなり，比䍊的小寸法のものが多量に出るのであり ますが，鋼优の場合ですと，再遮延によつてこれを小 さい寸法のまのに變える。そして使用するというるう

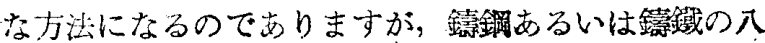

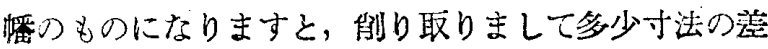
のある8のは利用できますけれども，ごく小さいもの は再豁解する汪かにあまり途がないように思いますが， それにつきましては容解蠝で熔かしますのに，古まり 大きなものを使うことはできませんので，熔銑盛であ りますと 100 キロかその程度までより使用できない のでありますが，こ礼を利用するのに，反射膚による とそういう大型のものを再焀解するに貿型にゆくので ありまして，燃料の解泛さへつ忛ば，こういう種類の

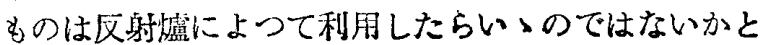
洘えております。また平盧でもあまり大きいものは燈 かすのに挿入あるいは敁解に因罋を感ずるだろうと思 いますか，私の所などでは大治の30 インチあるいは それ以上のもの，あるいはクロムとかはいつてきまし て，これを熔解するのに非常に团難しております。電 氣蠦の天井を動かし得るタイプにして溶解するのが一 番いつのではないかと諰つております。

横田幹事 それでは䦗本さんにお願いいたします。

岡本私何も準借して參りませんが，私見として 少し申上げさせて戴きます．今後材料と申しますと， 皆さんのお話のように大變不自由することがしばらく 續くたろうと思います。この場合もう少し鑄物として 鑄鐵のようなものをもつと活用できるのではないかと 洘えます. 從來は譸驖と申しますとあまりに粗末のも

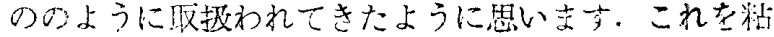

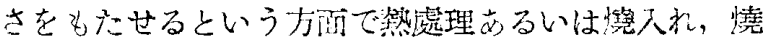
㞔しというようなこと艾技猃的に上手に取报うなら睍 在の材料の不足したときに役に立つものがだるるだ はないかというふうに䍐つています。そういう力面で もつと改良され閣心が淿われていつのではないかと思 います。

横田幹事つつぎに材料つ有郊なる使用法として， 限られた材翻をもつと有效に使用する手段を構じなけ ればならぬと䍐います。こつには材貿の强度を高方る

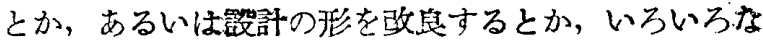
望味においてもつとぎりぎりな殷計ができるというよ うなこともありましようし，字た加工法によつては， 從來大きな鑄物を造れなかつたものは，先瑟もお話の あつたように，あまり大きな篅要はないということも

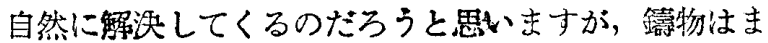

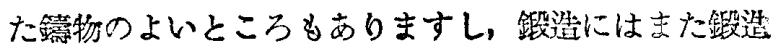
のよいところがありますから、これらもやはりできる たけ使用量を減らすことによつて材䝲を有效に使うと いう方法もまた考えられるのではないかと思います。 おのおの皆特政かるから，六の分野に委してゆくと いうことが必贸であります。なおそのほかに熔接を用 いて重量を輕くし，工數を節約いたすやり方むあると 思います。これに對しまして二三の方の御害見を伺い

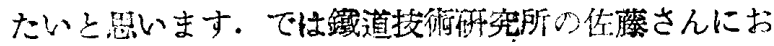
願いしたいと思います。

佐藤委員 Wまのお話のことは戰時中に大分盛ん にやられたようでありまして，たとえばブレスを感ん に利用する、苩のおるちや屋さんの技泪を利用したり した. たがいまお話がありましたが賽際やつてみると なかなかうまくいかなかつたように思います。節約を するというためにそういう特殊な方法を使うというこ とはなかなかむつかしい問題のように思いますか，私 は直接やつておりませんので具嚂的な內容はどうもわ かりません。

横田幹事鑄物の方を加山さんから一つお話䫝い ます.

加山委員 戰時中に私は埶王エンジンを浩れとい われまして，參教にやつたこと留ありますが，穴の設

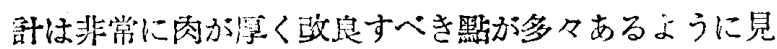
受けられました。戰時多忙のため古い浔阡そのま〉を 探用したものと思いますが，布和な溚付いた時代とな

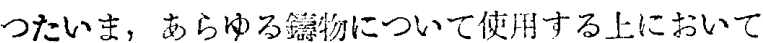
また热作する上において゚り易いように設計を根本的

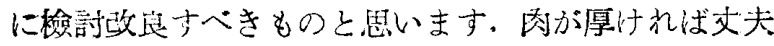
なものができるという栲え方で聳來鑄物の設計が行わ れていたように思いますが，䌧物特に鑄瀻の場合には そ扎は間堂つている。强度は因愿に比例しない，かえ つて暻肉部には引け雀ができ强度も弱まり鑄物もしが 


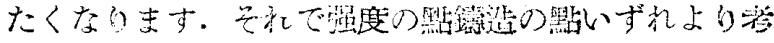

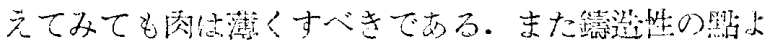

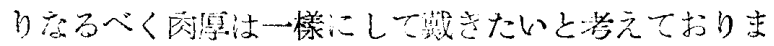

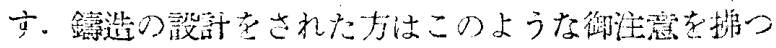
て器きたい上鼠いきす。

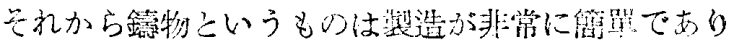

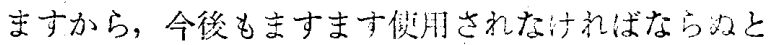

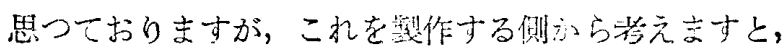

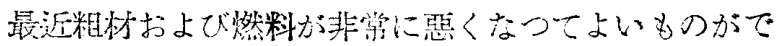
きない，关のために銀物の信用がなくなるというよう な彇沉にありまして，これを何と加撋しなければな bません．私共としまして非常な珼任を愈して就り，

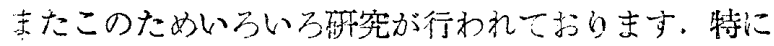
いま困つております問題は粗惡コークスの問題であり， この方面の研究も相當行われて扔ります。たとえば微 粉コークスを菓炭のように圖めるとか，カーパイト滓 のようなもの立まろ゙すとかして火持ちをよくさせる。 あるいはまた電㥛㕍を混用するとか，いろいろの打法 が考えられ䅡啗の成績を擧げて坊ります。なおまた孯 いコークスを使用する場合の配合材料の對策として地 金を細かく碎くことがよいのですが，銑鐵などが大き くて割るのが非常に困るという譬を開いておりますが， 銑墥はなるべく細かく割り易い形狀に作つて戴きたい. これは鑄物業者の絕えずいつておることですが，日鐵 のオアもお出でのことですが，この贸如何なものであ りましようか．鑄物業者の切實な要求をかなえて戴き †いと照います。

横田幹事第定の時間も參りましたので，最後に 诽俗さんに總括的に座談會の御感想を一つ去潰いいた したいと䍐います。

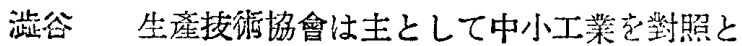
して技獄的發屋の協議にあずかることになつておりま すか，業哭の方も落ちつかず協會の方も十分整備致し ており立せんので，お互に仕事がいだ勘道に乘つて

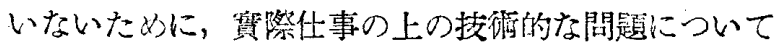
は稌り相談を持ちかけて來られませ女が，材料の閵超 についてはいろいろと荌求がありまして，私が協會の

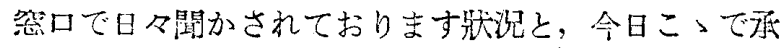
つた座談會のお話とを對照致しますと，少しも異なる ところなくぴつたりと符合致して势りまして基だ喟味

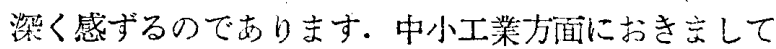
も，近琴手持材料が次第に虽乏したと兒えまして，殊 に細物薄物の要求が著しく增加してきました。さらに 間題となりますのは鑄鐵物で文り寺す。な化學整品

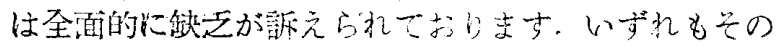

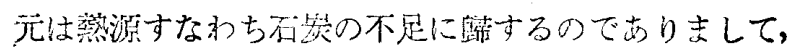

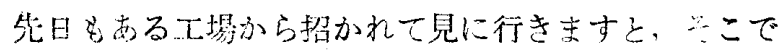

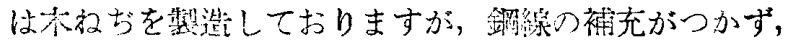

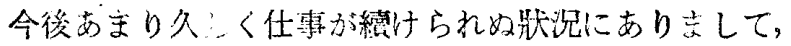

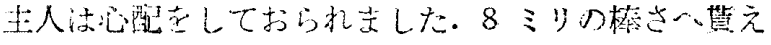

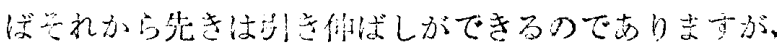

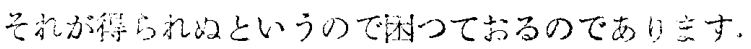

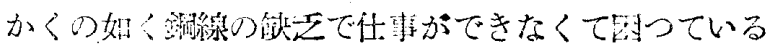

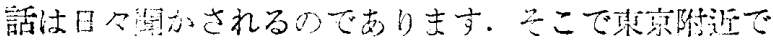

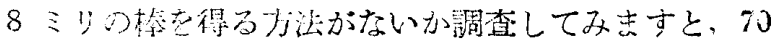

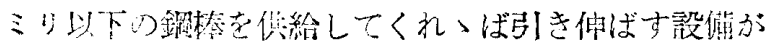
町工埸にもあるということであります。これもさらに

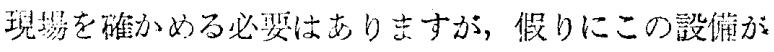

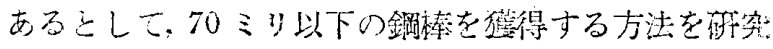

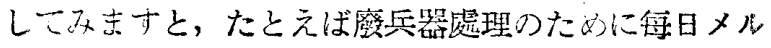
トしつ、あるスクラップから小さな鈯塊を作り, 手近 にある中型ロールでロールすれば，淔ちに遒寸の鎆棒 が待られるのでありますが，それに必要な石灰がない ために，それが代れない，石炭は手近な常艋地方にあ， るがこれを理ぶことができないというようなことでき

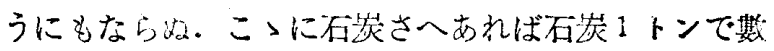

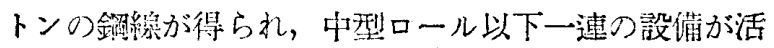

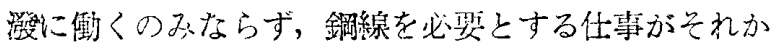
らそれへと㫱き出すのであります。結局詮じつぬれば

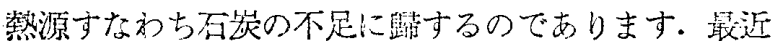

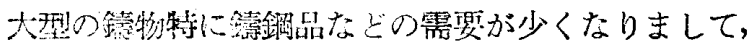
大型弁の整连工場などでは仕事がなくなつて团つてお

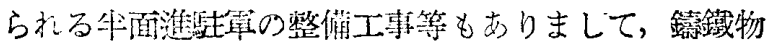
の镐望が塯加し突發的に起りますが，コークス不足の

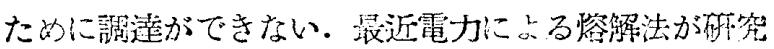

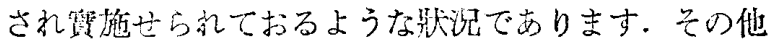

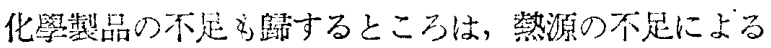
ものであります．かくの如く材料需給調筫の系口何 にもか子石炭であります. 顽唡は日一日と深刻の度を

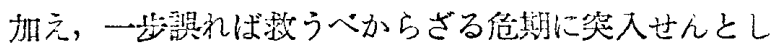
つメあること注前に申した通りで交り立す。われわれ

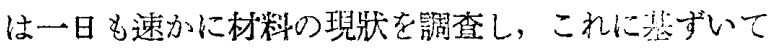
材科教國の方策を樹立しなければなら内と罢うのであ ります。

・つぎに本日の䦭䁲になりました特殊鍶利用の件につ きましては，これを二つに分けて考える必翏がある

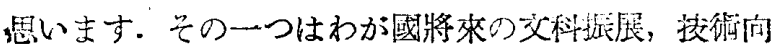
上，整品侵良化のためにぜひと特殊鍼を使用しなけ ればなら收ものに對しましては，將花わが國に扗いて その特殊鋼が谷易に得られるということを條件としな ければならぬ. 現在特殊鍼の手持が愣山あるというの で將來の見透しもなく鱓暗に使用せんとすることは禁 物である，他の一つとしては資材の不足を補なうため に停渄凟材を活用せんとする一眭的の便法の意味にお

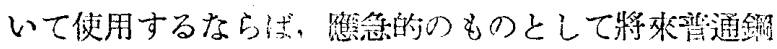

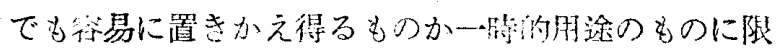

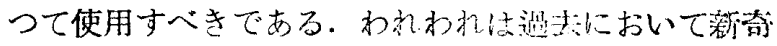

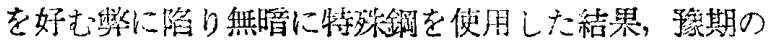




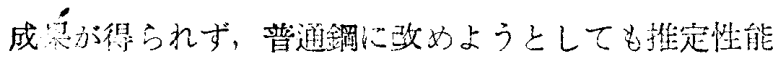

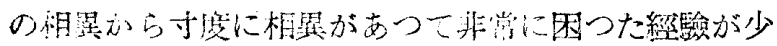

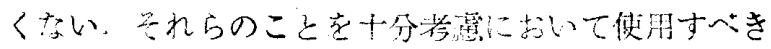

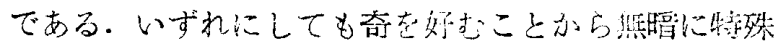
鈵を使用せんとすることはよろしくない。できるだけ 平羿な材料で間に合せるように工夫するのが深㫜であ

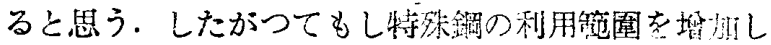
ようとするならば，まずもつて山眮トランスポーテー

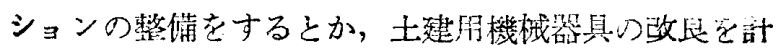
るとか技猃上の淮步を促しつっこれにマッチしてその

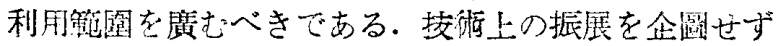
して特殊鋁の消化を增加せしめむとすることは管道で

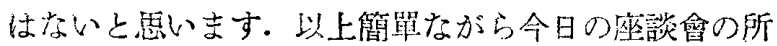
晃として申上げ立す。

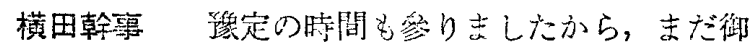

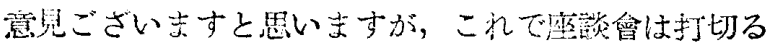

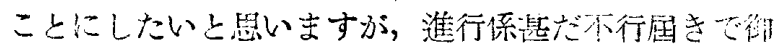

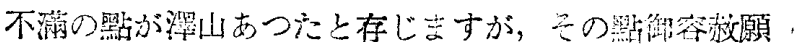
いたいと思います，䐴曾の簤を座長にお愿いします。

山內委員長 長時間にわたりそれ方のの间題につ いて缕藏なく御話し下さいましたこと孛く御禮申上

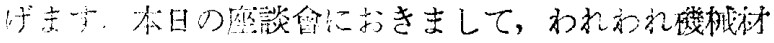

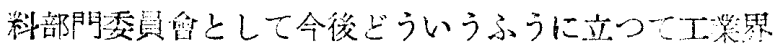

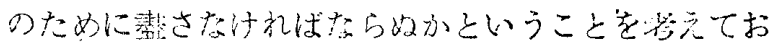

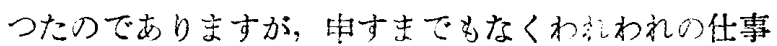

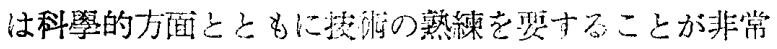

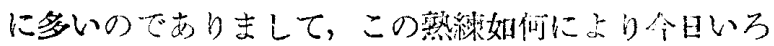

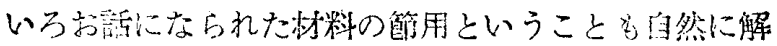

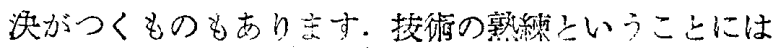

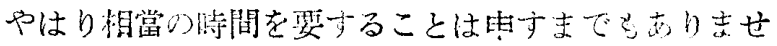
んが，こ礼を如湖にして早く雔鄱させるかということ

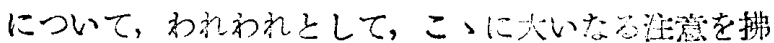

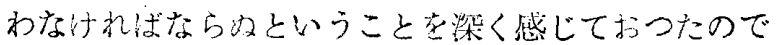

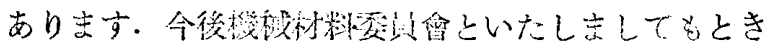

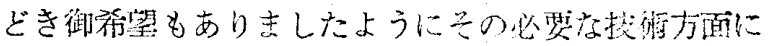

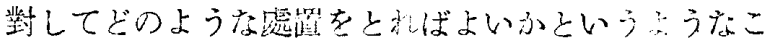

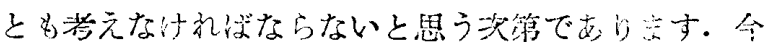

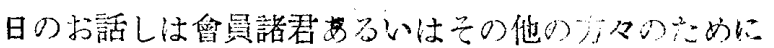
当御參考になり得たことと存します。愿く御䄚舅上げ ます。

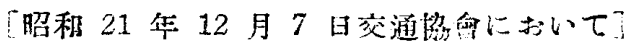

